\title{
Heavy Metal Bioaccumulation and Lipid Peroxidation Damage in Residents of a Gas Flaring Community
}

\author{
Ifenkwe John C. ${ }^{1}$, Nwanjo Harrison $\mathrm{U}^{2}$, Nwosu Dennis $\mathrm{C}^{3}$, Solomon Ederi $\mathrm{A}^{4}$ and Bot Yakubu $\mathrm{S}^{5}$ \\ ${ }^{1}$ Health Check Integrated Services
}

193, Chief Melford Okilo Way, Onopa, Yenagoa, Bayelsa State, Nigeria

${ }^{2,3}$ Imo State University, Owerri, Nigeria

${ }^{4}$ Federal Medical Centre, Yenagoa, Nigeria

${ }^{5}$ University of Jos, Nigeria

\begin{abstract}
In this study, blood samples collected from 200 residents each from Imiringi (Gas Flaring Community) and Odi (Non-Gas Flaring Community) all in Bayelsa State, Nigeria was analyzed to determine the levels of Cadmium, Chromium, Lead, Mercury, Selenium and also the lipid peroxidation oxidative stress marker- 8-Iso-Prostagladin $\mathrm{F}_{2} \alpha$ (8-Iso- $\mathrm{PGF}_{2} \alpha$ ). Blood samples were equally analyzed for $\mathrm{Hb}, \mathrm{WBC}$, platelets, prothrombin time and serum concentrations of AST, ALT, albumin, ALP, bilirubin, gamma GT, total protein, sodium, potassium, chloride, bicarbonate, urea and creatinine. Significantly higher levels of Cadmium, Chromium Mercury, Lead, Selenium and 8-Iso- $\mathrm{PGF}_{2} \alpha$ were observed in residents from Imiringi $(\mathrm{P}<0.05)$. Imiringi residents also had the highest mean values of all the measured liver and kidney functions parameters excluding albumin, total protein, sodium, chloride and bicarbonate and these values were all statistically different at $\mathrm{P}<0.05$. Differences in blood levels of $\mathrm{Hb}, \mathrm{WBC}$ and Platelets were equally significant while the length of bleeding time was significantly prolonged in the residents of Imiringi community. The findings of this study suggest that the probability of occurrence of diseases associated with metal toxicity and lipid peroxidation damage might be higher among residents in the gas flaring community.
\end{abstract}

Keywords: Lipid Peroxidation, Bioaccumulation, Heavy Metal, Oxidative Stress, Reactive Oxygen Species Gas Flaring.

\section{INTRODUCTION}

Bayelsa State located in the Niger Delta region of Southern Nigeria is a centre of oil and gas production activities such as drilling, storage, refining and transportation of products. In achieving these activities, large amounts of petroleum products and its wastes are discharged into the surrounding environments. Due to insufficient investment made on infrastructure to utilize natural gas associated with oil drilling, the gas is usually flared openly in the surrounding environment. Nigeria flares about 17.2 billion $\mathrm{cm}^{3}$ of natural gas every year in conjunction with the exploration of crude oil in the Niger Delta [1]. This high level of gas flaring is equal to approximately one quarter of the current gas consumption of the African continent.

Different proportions of heavy metals namely Zinc ( $\mathrm{Zn})$, Lead $(\mathrm{Pb})$ Manganese (Mn), Chromium (Cr), Cadmium (Cd), Iron (Fe), Nickel (Ni), Cobalt (Co), Vanadium (Vd), Mercury (Hg), Copper $(\mathrm{Cu})$, Molybdenum (Mo) and Selenium (Se) are found in crude oil with Nigeria crude oils having relatively high concentrations of $\mathrm{Fe}, \mathrm{Zn}, \mathrm{Cu}, \mathrm{Pb}$ and $\mathrm{Hg}$ [2].

Heavy metals represent a unique aspect of toxicology because they do not undergo breakdown into other metals. Quite unlike organic contaminants, they are not degraded further and also cannot decompose into other chemicals in course of time [3]. These result to their bioaccumulation in the ecosystem, agriculture and the human body exhibiting toxicity at low concentrations and such toxic effects can be long lasting. Most of the toxicologically important metals bind strongly to tissues, and are only excreted slowly therefore, they tend to accumulate on continued exposure. Affinities for different tissues vary significantly. Elements such as lead are bound in the bones while mercury and cadmium localize in the kidneys [4]. A peculiar feature of these xenobiotics is the induction of oxidative stress [5]. 
Oxidative Stress is essentially a condition characterized by an imbalance between the production (concentration) of Reactive Oxygen Species (ROS) and antioxidants in the body. Excessive accumulation of ROS will lead to cell injury due to damage to nuclear materials (DNA/RNA), proteins, lipid membranes or by oxidatively inactivating specific enzymes by oxidation of Cofactors [6]. Oxidative stress is now recognized to be a prominent feature of many acute and chronic diseases including cancer, cardiovascular disease, neurodegenerative disease, lung disease and even the normal aging process. However, definitive evidence for this association had been lacking due to recognized shortcomings with methods available to assess oxidative stress status in vivo in humans (1). Several in vitro markers of oxidative stress are available, but many are of limited value in vivo because they lack sensitivity and/or specificity or require invasive analytical methods [7]. The most widely used test for lipid peroxidation and oxidative stress is measurement of Malondialdehyde (MDA), a product of lipid peroxidation, by a thiobarbituric acid-reacting substances (TBARS) assay [8]. However, the use of this assay to assess oxidative stress status is problematic because MDA is not a specific product of lipid peroxidation and the TBARS assay is not specific for MDA [9]. Though various methods have been used to measure lipid hydro peroxides, but marked inconsistencies have been found with levels detected, raising questions regarding accuracy of assay methodology [10]. Lipid hydro peroxides cannot be detected in circulation even under conditions of severe oxidative stress using a highly accurate and sensitive gas chromatography/mass spectrometry (GC/MS) assay, rendering this approach for assessing oxidative stress status in humans of little or no value. F2 Isoprostanes are considered the best available biomarkers of oxidative stress status and lipid peroxidation in vivo [7].

Isoprostanes are a group of prostaglandin-like compounds that are produced in vivo from a non-enzymatic mechanism involving free radical initiated peroxidation of arachidonic acid (polyunsaturated omega-6 fatty acid). Production of isoprostanes is well documented to increase in direct proportion to the level of oxidative stress [7]. Measurement of F2-isoprostanes has numerous advantages over other quantitative markers of oxidative stress. F2-Isoprostanes are: (1) chemically stable, (2) specific products of lipid peroxidation, (3) formed in vivo, (4) present in detectable amounts in all normal tissues and biological fluids thus, allowing definition of a normal range, (5) levels increase substantially in animal models of oxidant injury (6) unaffected by lipid content in the diet [11] [12] and (7) might provide a sensitive biochemical basis in dose-finding studies with antioxidants [7]. Measurement of F2-isoprostanes in tissues and/or biological fluids provides a valuable new approach to the quantification of oxidative stress as well as a biochemical basis for assessing therapeutic intervention. Measurement of the level of lipid peroxidation as reflected by F2-isoprostane concentrations in biological fluids may help to identify those patients most likely to benefit from antioxidant treatment. The discovery of isoprostanes and measurement of F2-isoprostanes has emerged as one of the most reliable approaches to assess oxidative stress status in vivo, providing an important tool to explore the role of oxidative stress in the pathogenesis of human disease. Though the Niger Delta area has grown to be fairly dependent on oil and has equally become the center of current industrial development as well as economic activities, considerations are rarely made on how oil exploration processes create environmental, health, and social problems in local communities near oil producing fields. Flaring of petrochemical gas causes significant rise of temperature or thermal gradient of the surrounding environment and also the release of many associated combustion products such as oxides of carbon, nitrogen and sulphur $\left(\mathrm{CO}_{2}, \mathrm{NO}\right.$ and $\left.\mathrm{SO}_{2}\right)$, photochemical oxidants [13]. Gas flaring in the Niger Delta region contributes approximately 35 million metric tons of $\mathrm{CO}_{2}$ per year [14]. Acid rains have been linked to gas flaring due to the emission of higher than normal amounts of $\mathrm{NO}$ and $\mathrm{SO} 2$ which combine with atmospheric moisture to form nitric acid and sulfuric acid respectively. Acid rain can induce the mobilization of several toxic metals like mercury, lead, cadmium, arsenic and selenium [15]. Water sources from gas flared areas have raised levels of conductivity, total dissolved solids, total hardness, temperature, chemical oxygen demand, chloride, nitrate, nitrites, sulfates, zinc and potassium above the WHO acceptable limits for drinking water [16]. They also have higher concentrations of heavy metals such as cadmium, selenium, lead, manganese and than non-gas flared areas [16]. This makes water from these sources unsuitable for human consumption.

A peculiar feature of these xenobiotics is the induction of oxidative stress [5].

With these stated facts, it becomes expedient to assess the levels of heavy metals and oxidative stress markers in residents of these communities who are exposed to the flared gases, drink from the polluted water, eat plants harvested from the surrounding soil and equally consume aquatic species found in these environments. Bearing in mind the cumulative health effects that may result from the stated problems, this study tried to explore the impact of gas flaring on human health to improve mitigation efforts and also to prevent adverse health effects on individuals living in affected communities.

\section{MATERIALS AND METHODS}

\subsection{Study Community}

This study was carried out in two communities in Bayelsa state.

(a) Imringi Community (Gas Flaring Community). It is located within Kolo Creek in Ogbia Local Government Area of Bayelsa State. Gas flaring activity here is operated by the Shell Petroleum Development Company (SPDC) and has been on for over 30 years. 
(b) Odi Community (Non-Oil Producing and Non-Gas Flaring Community).The community is located in Kolokuma/Opokuma Local Government Area of Bayelsa state.

Both communities are located in Bayelsa State, which lies within, latitude $04^{0} 15^{1}$ North, $05^{0} 23^{1}$ South and longitude $05^{0} 22^{1}$ West and $06^{0} 45^{1}$ East [10]. Imiringi is the test community while Odi community served as control.

\subsection{Study Population}

200 participants were recruited from Imiringi (Oil Producing Community) and another 200 from Odi (Non-Gas Flaring Community). 84 out of the 200 subjects from Imiringi community were males between 2 - 80 years. 116 were females between 2 78 years. In Odi community, 106 were males between $2-80$ years while 94 were females aged between $2-79$ years.

\subsection{Advocacy and Mobilization}

The Bayelsa State Ministry of Health granted the ethical clearance for this work. The traditional rulers as well as members and leaders of the community development committees of each community were met and informed about the study that was to be carried out in their various communities. Their co-operation and support were solicited in mobilizing their subjects and informed consent was obtained from the subjects recruited into the study.

\subsection{Selection Criteria}

Information needed for inclusion or exclusion of participants was obtained using a questionnaire.

\subsubsection{Inclusion Criteria}

Subjects two years and above that consented were included. The sample population was classified according to sex and age groups.

\subsubsection{Exclusion Criteria}

Subjects with known illnesses such as cancer, diabetes mellitus and Parkinson's disease as well as tobacco smokers were excluded from this study. This is because cigarette smoke is an exogenous source of oxidative stress [11] while levels of oxidative stress biomarkers are known to be raised in the above mentioned disease conditions [12].

\subsection{Sample Collection}

Blood samples were collected by venepuncture using pyrogen free sterile disposable syringes. Samples for measurement of 8Isoprostane and biochemical parameters were collected into plain serum separating tubes. These were allowed to stand for 10-20 minutes after which they were centrifuged at 3,000 rpm for 20 minutes and the serum separated using a Pasteur's pipette. Samples for measurement of haematological parameters (prothrombin time not inclusive) and heavy metals were collected into $\mathrm{K}_{3}$ EDTA anti coagulated plastic bottles and mixed thoroughly by gentle repeated turning. Samples for prothrombin time were dispensed into containers containing 3.2\% tri sodium citrate at a ratio of 9 parts of blood to 1 part of $3.2 \%$ tri sodium citrate. The samples were centrifuged for 15 minutes at $3000 \mathrm{rpm}$ to obtain platelet poor plasma. The supernatant plasma was subsequently transferred into plain appendorf tubes.

\subsection{Laboratory Procedures}

All the reagents used were commercially purchased from Afro Famous Nigeria Limited, Abakpa Nike, Enugu, Enugu State and all manufacturers' SOPs were followed strictly.

(A) Measurement of $\mathrm{Cd}, \mathrm{Cr}, \mathrm{Hg}, \mathrm{Pb}$ and $\mathrm{Se}$

240 FS AA Agilent Technologies flame atomic absorption spectrometer with deuterium lamp background correction was used for the measurement of these metals.

(B) 8- Isoprostaglandin $\mathbf{F}_{2} \boldsymbol{\alpha}\left(\mathbf{8}-\right.$ Iso- $\left._{\text {PGF }} \boldsymbol{\alpha}\right)$ [13].The Elabscience 8-Iso-PGF 2 competitive ELISA technique kit was used for the quantitative measurement of 8 -Isoprostane in the test subjects.

(C) Albumin [18].

RANDOX Albumin test kit was used.

(D) Bilirubin [19]

RANDOX Bilirubin kit was used.

(E) Alkaline Phosphatase (ALP) [20].

TECO Diagnostics, California, USA direct colorimetric ALP reagent kit was used.

(F) Gamma-glutamyl Transferase ( $\gamma$-GT) [20]. 
RANDOX colorimetric (Kinetic Method) test kit was used.

(G) Alanine Aminotransferase (ALT) [21]

RANDOX ALT kit was used.

(H) Aspartate Aminotransferase (AST) [21]

RANDOX AST test kit was used.

(I) Urea [19]

RANDOX Urease-Berthelot Colorimetric method kit was used.

(J) Creatinine [22].

RANDOX Creatinine kit was used.

(K) Electrolytes $\left(\mathrm{Na}^{+}, \mathrm{K}^{+}, \mathrm{Cl}^{-}, \mathrm{HCO3}^{-}\right)$[23].

EA-1000B ISE electrolyte analyzer from Perlong Medical Equipment Company was used to measure these parameters.

(L) Platelets, Haemoglobin (Hb) [24]

SYSMEX pocH-100i automated haematology analyzer was used to measure these parameters.

(M) Prothrombin Time (PT) [25].

AGAPE Diagnostics Switzerland Prothrombin Time kit was used.

\subsection{Statistical Analysis}

Data obtained was analyzed using Statistical Package for Social Sciences (SPSS) statistical software (Version 17 for windows) (SPSS Inc, Chicago, USA). Results were presented in tables as mean and standard deviation. Z-Test, Pearson correlation coefficient statistics and Tukey HSD post HOC test were used to test for significance of the results. Values above $95 \%$ confidence limit were considered statistically significant.

\section{RESULTS}

Table 1 shows serum 8-Iso-PGF $2 \alpha$ and blood heavy metal concentrations measured in the two study groups. Highest levels of all the measured heavy metals and 8 -Iso- $\mathrm{PGF}_{2} \alpha$ were observed in subjects residing in Imiringi community and Z-test of the means of the two groups showed statistically significant differences for all the measured metals and 8 -Iso-PGF $\alpha$ ( $<<0.05$ )

Table 1: Heavy Metal and 8-Iso-PGF $2 \alpha$ Levels in the Study Populations.

\begin{tabular}{|l|l|l|l|l|l|l|}
\hline $\begin{array}{l}\text { Study } \\
\text { Community }\end{array}$ & Cd(ppm) & Cr(ppm & Hg(ppm) & Pb(ppm) & Se(ppm) & 8-Iso-PGF $\alpha(\mathbf{p g} / \mathbf{m l})$ \\
\hline $\begin{array}{l}\text { Imiringi } \\
(\mathbf{n}=\mathbf{2 0 0})\end{array}$ & $0.030 \pm 0.006$ & $0.026 \pm 0.009$ & $0.829 \pm 0.206$ & $10.794 \pm 1.513$ & $2.418 \pm 0.893$ & $492.30 \pm 357$ \\
\hline $\begin{array}{l}\text { Odi } \\
(\mathbf{n}=\mathbf{2 0 0})\end{array}$ & $0.017 \pm 0.01$ & $0.004 \pm 0.011$ & $0.081 \pm 0.098$ & $0.929 \pm 0.314$ & $0.037 \pm 0.064$ & $314.00 \pm 202.35$ \\
\hline P Value & $<0.0001(\mathrm{~S})$ & $<0.0001(\mathrm{~S})$ & $<0.0001(\mathrm{~S})$ & $<0.0001(\mathrm{~S})$ & $<0.0001(\mathrm{~S})$ & $<0.0001(\mathrm{~S})$ \\
\hline
\end{tabular}

\section{S=Significant}

Table 2 is a presentation of the effect of gender induced differences on the bioaccumulation of the measured metals and 8-Iso$\mathrm{PGF}_{2} \alpha$ in the two groups. It shows that females in Imiringi community had higher values of all the measured heavy metals and 8 Iso- $\mathrm{PGF}_{2} \alpha$ than males These observed variations in concentrations among the two sub-groups were statistically significant in only selenium and 8 -Iso- $\mathrm{PGF}_{2} \alpha$ at $\mathrm{P}<0.05$ (Table 2). Results from Odi community show that females had higher mean values of cadmium, chromium, lead and 8 -Iso- $\mathrm{PGF}_{2} \alpha$ while males had higher mean values of Mercury and selenium than females. These observed differences were significant in 8-Iso- $\mathrm{PGF}_{2} \alpha$ and all the measured metals except in cadmium and lead (Table 2).The mean concentrations of the measured heavy metals and $8-\mathrm{Iso}_{-} \mathrm{PGF}_{2} \alpha$ in the different age groups of Imiringi community are presented in table 3. Test of significance of these observed age induced differences using Tukey Post HOC analysis are presented in table 4. The highest mean level of cadmium was observed in residents $51-60$ years old $(0.034 \pm 0.005 \mathrm{ppm})$ while the least mean level $(0.03 \pm 0.01 \mathrm{ppm})$ was observed in residents $71-80$ years old. These values were not statistically different at $\mathrm{P}<0.05$ (Table 4$)$. The highest mean value of chromium $(0.032 \pm 0.013 \mathrm{ppm})$ was recorded in the age group 31-40 years while the least value $(0.020$ $\pm 0.003 \mathrm{ppm})$ was recorded among residents $2-10$ years old. This observed difference was not statistically significant. 
Ifenkwe john C. et. al., Heavy Metal Bioaccumulation And Lipid Peroxidation Damage

Table 2: Heavy Metals and 8-Iso-PGF $2 \alpha$ Levels in Males and Females.

\begin{tabular}{|c|c|c|c|c|c|c|c|c|}
\hline \multicolumn{5}{|c|}{ Imiringi } & \multicolumn{4}{|l|}{ Odi } \\
\hline & $\begin{array}{c}\text { Males } \\
n=84\end{array}$ & $\begin{array}{c}\begin{array}{c}\text { Females } \\
n=116\end{array}\end{array}$ & F value & $P$ value & $\begin{array}{l}\text { Males } \\
\mathrm{n}=106\end{array}$ & $\begin{array}{l}\text { Females } \\
\mathrm{n}=94\end{array}$ & F value & P value \\
\hline $\mathbf{C d}(p p m)$ & $0.030 \pm 0.006$ & $0.031 \pm 0.007$ & 1.119 & 0.292 & $0.017 \pm 0.014$ & $0.018 \pm 0.006$ & 0.412 & 0.522 \\
\hline $\mathrm{Cr}(\mathbf{p p m})$ & $0.025 \pm 0.010$ & $0.026 \pm 0.01$ & 0.487 & 0.486 & $0.004 \pm 0.013$ & $0.0041 \pm 0.009$ & 505.75 & $<0.0001(S)$ \\
\hline $\mathbf{H g}(\mathbf{p p m})$ & $0.817 \pm 0.19$ & $0.84 \pm 0.225$ & 0.579 & 0.448 & $0.109 \pm 0.122$ & $0.052 \pm 0.06$ & 16.89 & $<0.0001(\mathrm{~S})$ \\
\hline $\mathrm{Pb}(\mathbf{p p m})$ & $10.626 \pm 1.8$ & $10.91 \pm 1.36$ & 1.580 & 0.210 & $0.732 \pm 0.212$ & $0.741 \pm 0.18$ & 0.103 & 0.748 \\
\hline Se(ppm) & $2.35 \pm 1.09$ & $3.136 \pm 1.32$ & 6.123 & $0.014(\mathrm{~S})$ & $0.051 \pm 0.07$ & $0.022 \pm 0.05$ & 10.56 & $0.001(\mathrm{~S})$ \\
\hline $\begin{array}{l}\text { 8-Iso-PGF }{ }_{2} \alpha \\
(\mathrm{pg} / \mathrm{ml})\end{array}$ & $508 \pm 368.75$ & $\begin{array}{l}513.33 \pm \\
389.69\end{array}$ & 0.922 & $0.01(\mathrm{~S})$ & $259 \pm 104$ & $284.45 \pm 127$ & 2.434 & 0.120 \\
\hline
\end{tabular}

$\mathrm{S}=$ Significant

Table 3: Heavy Metals and 8-Iso-PGF $2 \alpha$ Levels in Subjects in Relation to Age in Imiringi Community.

\begin{tabular}{|c|c|c|c|c|c|c|}
\hline Age Range & Cd(ppm) & Cr(ppm & $\mathbf{H g}(\mathbf{p p m})$ & $\mathrm{Pb}(\mathbf{p p m})$ & $\operatorname{Se}(p p m)$ & 8-Iso-PGF ${ }_{2} \alpha(\mathrm{pg} / \mathrm{ml})$ \\
\hline $2-10(n=30)$ & $0.020 \pm 0.004$ & $0.020 \pm 0.003$ & $0.436 \pm 0.142$ & $9.14 \pm 0.81$ & $1.842 \pm 0.31$ & $206.30 \pm 97.11$ \\
\hline $11-20(n=34)$ & $0.025 \pm 0.006$ & $0.022 \pm 0.08$ & $0.835 \pm 0.12$ & $10.87 \pm 1.82$ & $2.043 \pm 0.37$ & $256.00 \pm 111.50$ \\
\hline $21-30(n=26)$ & $0.028 \pm 0.004$ & $0.027 \pm 0.006$ & $0.803 \pm 0.14$ & $10.654 \pm 1.31$ & $2.054 \pm 0.42$ & $274.30 \pm 103.60$ \\
\hline $31-40(n=30)$ & $0.029 \pm 0.005$ & $0.032 \pm 0.013$ & $0.820 \pm 0.21$ & $10.72 \pm 0.85$ & $2.098 \pm 0.42$ & $282 \pm 107$ \\
\hline $41-50(n=23)$ & $0.030 \pm 0.005$ & $0.028 \pm 0.009$ & $0.685 \pm 0.22$ & $9.864 \pm 0.77$ & $2.20 \pm 0.50$ & $576.40 \pm 202.40$ \\
\hline $51-60(n=25)$ & $0.034 \pm 0.005$ & $0.026 \pm 0.01$ & $0.696 \pm 0.23$ & $10.24 \pm 0.65$ & $2.50 \pm 0.87$ & $907.60 \pm 374.26$ \\
\hline $61-70(n=15)$ & $0.032 \pm 0.005$ & $0.025 \pm 0.008$ & $0.74 \pm 0.09$ & $10.87 \pm 0.55$ & $2.94 \pm 0.78$ & $775.60 \pm 304.81$ \\
\hline $71-80(n=17)$ & $0.03 \pm 0.01$ & $0.024 \pm 0.01$ & $0.971 \pm 0.08$ & $11.85 \pm 1.47$ & $3.14 \pm 1.32$ & $523.13 \pm 214.31$ \\
\hline
\end{tabular}

Subjects 71-80 years old, had the highest mean concentrations of mercury $(0.971 \pm 0.08 \mathrm{ppm})$, lead $(11.85 \pm 1.47 \mathrm{ppm})$ and selenium $(3.14 \pm 1.32 \mathrm{ppm})$ while those $2-10$ years old had the least values of all the three metals $(0.436 \pm 0.142 \mathrm{ppm}, 9.14 \pm$ $0.81 \mathrm{ppm}$ and $1.842 \pm 0.31 \mathrm{ppm}$ respectively). These differences were statistically significant (Table 4). Residents within the ages of $51-60$ years had the highest mean concentration of 8-Iso-PGF $\alpha(907.6 \pm 374.26 \mathrm{pg} / \mathrm{ml})$ while least levels of 8-Iso-PGF ${ }_{2} \alpha$ $(206.3 \pm 97.11 \mathrm{pg} / \mathrm{ml})$ was observed in residents between the ages of $2-10$ years. This age induced difference was not significant at $\mathrm{P}<0.05$.

The mean values of the measured heavy metals and 8-Isoprostane in the different age groups of Odi community are presented in table 5. Test of significance of these observed age induced differences using Tukey HSD post HOC test are presented in table 6. The highest mean value of cadmium $(0.022 \pm 0.01 \mathrm{ppm})$, Mercury $(0.097 \pm 0.08 \mathrm{ppm})$ and Selenium $(0.098 \pm 0.08 \mathrm{ppm})$ were recorded in residents between the ages of $71-80$ years. Highest mean values of Chromium $(0.038 \pm 0.07 \mathrm{ppm})$ and Lead $(0.919 \pm$ $0.25 \mathrm{ppm}$ ) were recorded in residents $11-20$ and $31-40$ years respectively. Children $2-10$ years old had the least mean values of cadmium $(0.012 \pm 0.008 \mathrm{ppm})$, Lead $(0.502 \pm 0.101 \mathrm{ppm})$ and selenium $(0.045 \pm 0.024 \mathrm{ppm})$. Least mean values of chromium $(0.001 \pm 0.001 \mathrm{ppm})$ and mercury $(0.001 \pm 0.001 \mathrm{ppm})$ were observed in residents $71-80$ and $21-30$ years respectively. These observed differences in these age groups were statistically different at $\mathrm{P}<0.05$. The highest mean concentration of 8-Iso-PGF $2 \alpha$ $(408.04 \pm 208.25 \mathrm{pg} / \mathrm{ml})$ was recorded in residents 71 -- 80 years old while residents that were between 2-10 years old had the least mean values. This measured difference was not significant. Table 7 shows the correlation between 8 -Iso- $\mathrm{PGF}_{2} \alpha$ and measured metals in Imiringi community. A weak and positive correlation was observed between all the metals and 8-Iso-PGF $2 \alpha$. These observed correlations were statistically significant at $\mathrm{P}<0.005$ except for selenium. Table 8 shows the mean values of the measured liver function parameters in the study groups. It shows that residents in Imiringi community had the highest mean values 
International Journal of Advances in Scientific Research and Engineering (ijasre), Vol 4 (7), July - 2018

of all the measured liver function parameters with the exception of albumin and total protein which were highest in the residents of Odi community. Results of the kidney function parameters measured in the study populations are presented in table 9 . The table shows that the highest levels of sodium $(141 \pm 2.2 \mathrm{mmol} / \mathrm{l})$, chloride $(103 \pm 3.6)$ and bicarbonate $(29.8 \pm 4.4)$ were recorded in residents in Odi. Residents in Imiringi had the highest levels of potassium $(4.4 \pm 0.4 \mathrm{mmol} / \mathrm{l})$, creatinine $(101 \pm 4.0 \mu \mathrm{mol} / \mathrm{l})$ and urea $\quad(6.6 \pm 1.0 \mathrm{mmol} / \mathrm{l})$. These differences were statistically significant $(\mathrm{p}<0.05)$.

Table 4: Comparison of Heavy Metals and 8-Isoprostane Levels in Subjects in Relation to Age in Imiringi Community.

\begin{tabular}{|c|c|c|c|c|c|c|}
\hline Age Range & Cd (P Value) & Cr (P Value) & Hg (PValue) & $\mathbf{P b}(\mathbf{P}$ Value $)$ & Se (P Value) & 8-Iso-PGF ${ }_{2} \alpha(P$ Value $)$ \\
\hline $2-10$ vs $11-20$ & 0.7391 & 1.0000 & $<0.0001(\mathrm{~S})$ & $<0.001(\mathrm{~S})$ & 0.9095 & 0.9742 \\
\hline $2-10$ vs $21-30$ & $<0.001(\mathrm{~S})$ & 0.9946 & $<0.0001(S)$ & $<0.001(\mathrm{~S})$ & 0.9155 & 0.9063 \\
\hline $2-10$ vs $31-40$ & $<0.001(\mathrm{~S})$ & 0.8737 & $<0.0001(\mathrm{~S})$ & $<0.001(\mathrm{~S})$ & 0.7695 & 0.8197 \\
\hline $2-10$ vs $41-50$ & $<0.001(\mathrm{~S})$ & 0.9902 & $<0.0001(\mathrm{~S})$ & 0.3155 & 0.4571 & $<0.001(S)$ \\
\hline $2-10$ vs $51-60$ & $<0.001(\mathrm{~S})$ & 0.9981 & $<0.0001(\mathrm{~S})$ & $0.0119(\mathrm{~S})$ & $0.0041(\mathrm{~S})$ & $<0.001(S)$ \\
\hline $2-10$ vs $61-70$ & $0.0334(\mathrm{~S})$ & 0.9998 & $<0.0001(\mathrm{~S})$ & $<0.001(\mathrm{~S})$ & $<0.001(\mathrm{~S})$ & $<0.001(S)$ \\
\hline $2-10$ vs $71-80$ & 0.1384 & 0.9999 & $<0.0001(\mathrm{~S})$ & $<0.0001(\mathrm{~S})$ & $<0.0001(\mathrm{~S})$ & $<0.001(S)$ \\
\hline $11-20$ vs $21-30$ & $0.0034(\mathrm{~S})$ & 0.9992 & 0.9959 & 0.9958 & 1.0000 & 1.0000 \\
\hline $11-20$ vs $31-40$ & $<0.001(\mathrm{~S})$ & 0.9397 & 1.0000 & 0.9995 & 1.0000 & 0.9995 \\
\hline $11-20$ vs $41-50$ & $<0.001(\mathrm{~S})$ & 0.9981 & $0.0237(\mathrm{~S})$ & $0.0301(\mathrm{~S})$ & 0.9839 & $<0.001(S)$ \\
\hline $11-20$ vs $51-60$ & 0.0483 & 0.9998 & $0.0391(\mathrm{~S})$ & 0.4328 & 0.1168 & $<0.001(S)$ \\
\hline $11-20$ vs $61-70$ & 0.5110 & 1.0000 & 0.6007 & 1.0000 & $0.0002(\mathrm{~S})$ & $<0.001(S)$ \\
\hline $11-20$ vs $71-80$ & 0.8723 & 1.0000 & 0.1190 & 0.0851 & $<0.001(\mathrm{~S})$ & $0.0003(S)$ \\
\hline $21-30$ vs $31-40$ & $0.005(\mathrm{~S})$ & 0.9994 & 0.9999 & 1.0000 & 1.0000 & 1.0000 \\
\hline $21-30$ vs $41-50$ & 0.9967 & 1.0000 & 0.2188 & 0.2540 & 0.9926 & $<0.001(S)$ \\
\hline $21-30$ vs $51-60$ & 0.9962 & 1.0000 & 0.3099 & 0.9081 & 0.1950 & $<0.001(S)$ \\
\hline $21-30$ vs $61-70$ & 0.9157 & 1.0000 & 0.9421 & 0.9990 & $0.0007(\mathrm{~S})$ & $<0.001(S)$ \\
\hline $21-30$ vs $71-80$ & 0.5193 & 1.0000 & $0.0322(\mathrm{~S})$ & $0.0218(\mathrm{~S})$ & $<0.001(\mathrm{~S})$ & $0.0021(S)$ \\
\hline $31-40$ vs $41-50$ & 0.0733 & 0.9999 & 0.0766 & 0.1337 & 0.9991 & $<0.001(S)$ \\
\hline $31-40$ vs $51-60$ & $0.0003(\mathrm{~S})$ & 0.9981 & 0.1189 & 0.7845 & 0.2747 & $<0.001(S)$ \\
\hline $31-40$ vs $61-70$ & $0.0003(\mathrm{~S})$ & 0.9981 & 0.8012 & 0.9999 & $<0.0001(\mathrm{~S})$ & $<0.001(S)$ \\
\hline $31-40$ vs $71-80$ & $<0.0001(\mathrm{~S})$ & 0.9943 & 0.0650 & $0.0304(\mathrm{~S})$ & $<0.0001(\mathrm{~S})$ & $0.0023(S)$ \\
\hline $41-50$ vs $51-60$ & 0.8553 & 1.0000 & 1.0000 & 0.9492 & 0.7249 & $<0.001(S)$ \\
\hline $41-50$ vs $61-70$ & 0.5995 & 1.0000 & 0.9755 & 0.1501 & $0.0122(\mathrm{~S})$ & 0.0565 \\
\hline $41-50$ vs $71-80$ & 0.1877 & 1.0000 & $<0.0001(\mathrm{~S})$ & $<0.0001(\mathrm{~S})$ & $0.0002(\mathrm{~S})$ & 0.9906 \\
\hline $51-60$ vs $61-70$ & 0.9986 & 1.0000 & 0.9927 & 0.7024 & 0.4003 & 0.4620 \\
\hline $51-60$ vs $71-80$ & 0.9020 & 1.0000 & $<0.0001(\mathrm{~S})$ & $0.0004(\mathrm{~S})$ & $0.0321(\mathrm{~S})$ & $<0.001(S)$ \\
\hline $61-70$ vs $71-80$ & 0.9992 & 1.0000 & $0.0033(\mathrm{~S})$ & 0.2452 & 0.9865 . & $0.009(S)$ \\
\hline
\end{tabular}

The mean levels of all the measured haematological parameters in the study communities are presented in table 10 . Statistically significant lower levels of $\mathrm{Hb}, \mathrm{WBC}$ and Platelet were observed in residents in the test community (Imiringi) ( $\mathrm{p}<0.05)$ compared to the control community (Odi). Subjects in Odi community recorded the highest levels of Hb (12.02 \pm 1 . 
Ifenkwe john C. et. al., Heavy Metal Bioaccumulation And Lipid Peroxidation Damage

$53 \mathrm{~g} / \mathrm{dl})$, WBC $\left(6.6 \pm 0.63 \times 10^{9} / \mathrm{l}\right)$ and Platelets $\left(208.5 \pm 7.52 \times 10^{9} / \mathrm{l}\right)$. On the other hand, the length of bleeding time was longer in the residents of Imiringi community (13.87 \pm 1.14 seconds) as compared to subjects from Odi community (12.74 \pm 1.09). These differences in prothrombin time in the two populations were statistically significant.

Table 5: Heavy Metals and 8-Iso-PGF $2 \alpha$ Levels in Subjects in Relation to Age in Odi Community.

\begin{tabular}{|l|l|l|l|l|l|l|}
\hline \multicolumn{1}{|c|}{ Age Range } & \multicolumn{1}{|c|}{ Cd(ppm) } & \multicolumn{1}{|c|}{ Cr(ppm } & \multicolumn{1}{|c|}{ Pg(ppm) } & \multicolumn{1}{|c|}{ Se(ppm) } & $\begin{array}{l}\text { 8-Iso-PGF } \mathbf{\alpha} \\
(\mathbf{p g} / \mathbf{m l})\end{array}$ \\
\hline $\mathbf{2 - 1 0 ( n = 2 7 )}$ & $0.012 \pm 0.008$ & $0.021 \pm 0.004$ & $0.016 \pm 0.014$ & $0.502 \pm 0.101$ & $0.045 \pm 0.024$ & $166.40 \pm 34.0$ \\
\hline $\mathbf{1 1 - 2 0 ( n = 3 6 )}$ & $0.018 \pm 0.004$ & $0.038 \pm 0.07$ & $0.021 \pm 0.02$ & $0.612 \pm 0.16$ & $0.081 \pm 0.011$ & $184.00 \pm 37.19$ \\
\hline $\mathbf{2 1 - 3 0 ( n = 2 6 )}$ & $0.016 \pm 0.004$ & $0.010 \pm 0.002$ & $0.001 \pm 0.001$ & $0.666 \pm 0.17$ & $0.056 \pm 0.063$ & $191.40 \pm 50.30$ \\
\hline $\mathbf{3 1 - 4 0 ( n = 3 2 )}$ & $0.013 \pm 0.003$ & $0.012 \pm 0.002$ & $0.002 \pm 0.002$ & $0.919 \pm 0.25$ & $0.055 \pm 0.05$ & $209.60 \pm 58.38$ \\
\hline $\mathbf{4 1 - 5 0 ( n = 2 0 )}$ & $0.014 \pm 0.002$ & $0.009 \pm 0.001$ & $0.06 \pm 0.04$ & $0.900 \pm 0.09$ & $0.057 \pm 0.004$ & $234.40 \pm 98.40$ \\
\hline $\mathbf{5 1 - 6 0 ( n = 2 1 )}$ & $0.016 \pm 0.02$ & $0.006 \pm 0.001$ & $0.06 \pm 0.04$ & $0.90 \pm 0.09$ & $0.060 \pm 0.04$ & $264.10 \pm 101.64$ \\
\hline $\mathbf{6 1 - 7 0 ( n = 2 0 )}$ & $0.017 \pm 0.01$ & $0.004 \pm 0.001$ & $0.07 \pm 0.08$ & $0.864 \pm 0.08$ & $0.065 \pm 0.07$ & $306.50 \pm 201.45$ \\
\hline $\mathbf{7 1 - ~ 8 0 ( n = 1 8 )}$ & $0.022 \pm 0.01$ & $0.001 \pm 0.001$ & $0.097 \pm 0.08$ & $0.818 \pm 0.08$ & $0.098 \pm 0.08$ & $408.04 \pm 208.25$ \\
\hline
\end{tabular}

Table 6: Comparison of Heavy Metals and 8-Isoprostane Levels in Different Age Groups in Odi Community

\begin{tabular}{|c|c|c|c|c|c|c|}
\hline Age Range & Cd (P Value) & Cr (P Value) & Hg (P Value) & $\mathrm{Pb}$ (P Value) & Se(P Value) & $\begin{array}{l}\text { 8-Iso-PGF }{ }_{2} \alpha \\
\text { (P Value) }\end{array}$ \\
\hline $2-10$ vs $11-20$ & 0.1445 & 0.2479 & 0.9999 & 0.0567 & 0.1371 & 0.9999 \\
\hline $2-10$ vs $21-30$ & 0.7280 & 0.8390 & 0.9458 & $0.0011(S)$ & 0.9950 & 0.9999 \\
\hline $2-10$ vs $31-40$ & 0.9999 & 0.9202 & 0.9509 & $<0.0001(S)$ & 0.9962 & 0.9999 \\
\hline $2-10$ vs $41-50$ & 0.9948 & 0.8275 & $0.0408(S)$ & $<0.0001(S)$ & 0.9945 & 1.0000 \\
\hline $2-10$ vs $51-60$ & 0.7821 & 0.5861 & $0.0359(\mathrm{~S})$ & $<0.0001(S)$ & 0.9776 & 0.9945 \\
\hline $2-10$ vs $61-70$ & 0.5493 & 0.4385 & $0.0039(S)$ & $<0.0001(S)$ & 0.9052 & 0.9997 \\
\hline $2-10$ vs $71-80$ & $0.0001(S)$ & 0.0616 & $<0.0001(S)$ & $<0.0001(S)$ & $0.0011(S)$ & 1.0000 \\
\hline $11-20$ vs $21-30$ & 0.9881 & 0.0031 & 0.7311 & 0.8256 & 0.5970 & 1.0000 \\
\hline $11-20$ vs $31-40$ & 0.2914 & 0.0039 & 0.7247 & $<0.0001(\mathrm{~S})$ & 0.4698 & 1.0000 \\
\hline $11-20$ vs $41-50$ & 0.7428 & 0.0058 & 0.0706 & $<0.0001(S)$ & 0.7344 & 1.0000 \\
\hline $11-20$ vs $51-60$ & 0.9919 & 0.0011 & 0.0623 & $<0.0001(S)$ & 0.8353 & 0.9998 \\
\hline $11-20$ vs $61-70$ & 0.9999 & 0.0005 & $0.0068(S)$ & $<0.0001(S)$ & 0.9596 & 1.0000 \\
\hline $11-20$ vs $71-80$ & 0.4583 & $.0001(S)$ & $<0.0001(S)$ & $<0.0001(S)$ & 0.8294 & 1.0000 \\
\hline $21-30$ vs $31-40$ & 0.9066 & 1.0000 & 1.0000 & $<0.0001(S)$ & 1.0000 & 1.0000 \\
\hline $21-30$ vs $41-50$ & 0.9950 & 1.0000 & $0.0011(\mathrm{~S})$ & $<0.0001(\mathrm{~S})$ & 1.0000 & 1.0000 \\
\hline $21-30$ vs $51-60$ & 1.0000 & 0.9997 & $0.0009(S)$ & $<0.0001(S)$ & 1.0000 & 1.0000 \\
\hline $21-30$ vs $61-70$ & 0.9999 & 0.9962 & $<0.0001(S)$ & $0.0002(S)$ & 0.9992 & 1.0000 \\
\hline $21-30$ vs $71-80$ & 0.1082 & 0.8878 & $<0.0001(S)$ & $0.0005(S)$ & $.0278(S)$ & 1.0000 \\
\hline $31-40$ vs $41-50$ & 0.9999 & 0.9999 & $0.0007(S)$ & 0.9998 & 1.0000 & 1.0000 \\
\hline $31-40$ vs $51-60$ & 0.9311 & 0.9946 & $0.0006(S)$ & 0.9998 & 1.0000 & 0.9999 \\
\hline $31-40$ vs $61-70$ & 0.7636 & 0.9729 & $<0.0001(S)$ & 0.8799 & 0.9978 & 1.0000 \\
\hline $31-40$ vs $71-80$ & $0.0004(S)$ & 0.6674 & $<0.0001(S)$ & $0.0461(\mathrm{~S})$ & 0.0105 (S & 1.0000 \\
\hline $41-50$ vs $51-60$ & 0.9963 & 1.0000 & 1.0000 & 1.0000 & 1.0000 & 0.9993 \\
\hline $41-50$ vs $61-70$ & 0.9630 & 0.9992 & 0.9978 & 0.9933 & 0.9997 & 1.0000 \\
\hline $41-50$ vs $71-80$ & $0.0191(S)$ & 0.9605 & 0.0739 & 0.3865 & 0.0754 & 1.0000 \\
\hline
\end{tabular}


International Journal of Advances in Scientific Research and Engineering (ijasre), Vol 4 (7), July - 2018

\begin{tabular}{|l|l|l|l|l|l|l|}
\hline $\mathbf{5 1 - 6 0}$ vs $\mathbf{6 1 - 7 0}$ & 1.0000 & 1.0000 & 0.9976 & 0.9927 & 1.0000 & 1.0000 \\
\hline $\mathbf{5 1 - 6 0}$ vs $\mathbf{7 1 - 8 0}$ & 0.1699 & 0.9973 & 0.0645 & 0.3637 & 0.1152 & 0.9999 \\
\hline $\mathbf{6 1 - 7 0}$ vs $\mathbf{7 1 - 8 0}$ & 0.4110 & 0.9999 & 0.3996 & 0.9295 & 0.2757 & 1.0000 \\
\hline
\end{tabular}

Table 7: Correlation between Measured Heavy Metals and 8-Iso-PGF $2 \alpha$ in Imiringi Community

\begin{tabular}{|c|c|c|c|c|c|c|c|c|c|c|}
\hline \multirow{2}{*}{ 8-Iso-PGF ${ }_{2} \alpha$} & \multicolumn{2}{|c|}{ Cd (ppm) } & \multicolumn{2}{|c|}{ Cr (ppm) } & \multicolumn{2}{|c|}{$\mathrm{Hg}$ (ppm) } & \multicolumn{2}{|c|}{$\mathrm{Pb}(\mathrm{ppm})$} & \multicolumn{2}{|c|}{ Se(ppm) } \\
\hline & $\mathbf{R}$ & $\mathbf{P}$ & $\mathbf{R}$ & $\mathbf{P}$ & $\mathbf{R}$ & $\mathbf{P}$ & $\overline{\mathbf{R}}$ & $\mathbf{P}$ & $\mathbf{R}$ & $\mathbf{P}$ \\
\hline & 0.183 & $0.009(S)$ & 0.175 & $0.013(\mathrm{~S})$ & 0.465 & $<0.0001(S)$ & 0.417 & $<0.0001(\mathrm{~S})$ & 0.074 & 0.298 \\
\hline
\end{tabular}

Table 8: Mean and SD Values of Liver Function Parameters in the Study Populations

\begin{tabular}{|l|l|l|l|l|l|l|l|l|}
\hline $\begin{array}{l}\text { STUDY } \\
\text { COMMUNITY } \\
\text { n= 200 }\end{array}$ & $\begin{array}{l}\text { ALT } \\
(\mathbf{U} / \mathbf{I})\end{array}$ & $\begin{array}{l}\text { AST } \\
(\mathbf{U} / \mathbf{I})\end{array}$ & $\begin{array}{l}\text { G-GT } \\
(\mathbf{U} / \mathbf{I})\end{array}$ & $\begin{array}{l}\text { ALP } \\
(\mathbf{U} / \mathbf{I})\end{array}$ & $\begin{array}{l}\text { Albumin } \\
(\mathbf{g} / \mathbf{l})\end{array}$ & $\begin{array}{l}\text { TP } \\
(\mathbf{g} / \mathbf{l})\end{array}$ & $\begin{array}{l}\text { TB } \\
(\mu \mathrm{mol} / \mathbf{l})\end{array}$ & $\begin{array}{l}\text { CB } \\
(\boldsymbol{\mu m o l} / \mathbf{l})\end{array}$ \\
\hline Imiringi & $7.2 \pm 1.6$ & $10.5 \pm 2$ & $40.4 \pm 3.3$ & $24 \pm 2$ & $37.4 \pm 3$ & $63 \pm 1$ & $9 \pm 0.88$ & $2.8 \pm 0.24$ \\
\hline Odi & $5.6 \pm 1.3$ & $9.5 \pm 1.8$ & $25.5 \pm 4.2$ & $22.3 \pm 1$ & $38.5 \pm 2$ & $63.8 \pm 1.3$ & $5.7 \pm 0.1$ & $2.0 \pm 0.11$ \\
\hline P Value & $<0.0001(\mathrm{~S})$ & $<0.0001(\mathrm{~S})$ & $<0.001(\mathrm{~S})$ & $<0.0001(\mathrm{~S})$ & $<0.0001(\mathrm{~S})$ & $<0.0001(\mathrm{~S})$ & $<0.0001(\mathrm{~S})$ & $<0.001(\mathrm{~S})$ \\
\hline
\end{tabular}

S = Significant

Table 9: Mean and SD Values of Kidney Function Parameters in the Study Populations.

\begin{tabular}{|l|l|l|l|l|l|l|}
\hline $\begin{array}{l}\text { Study } \\
\text { Community }\end{array}$ & $\begin{array}{l}\mathbf{N a}^{+} \\
(\mathbf{m m o l} / \mathbf{l})\end{array}$ & $\begin{array}{c}\mathbf{K}^{+} \\
(\mathbf{m m o l} / \mathbf{l})\end{array}$ & $\begin{array}{c}\mathbf{C l}^{-} \\
(\mathbf{m m o l} / \mathbf{l})\end{array}$ & $\begin{array}{c}\mathbf{H C O}_{\mathbf{3}}^{-} \\
(\mathbf{m m 0 1} / \mathbf{l})\end{array}$ & $\begin{array}{l}\text { Creatinine } \\
(\boldsymbol{\mu m o l} / \mathbf{l})\end{array}$ & $\begin{array}{l}\text { Urea } \\
(\mathbf{m m o l} / \mathbf{l})\end{array}$ \\
\hline Imiringi & $139 \pm 3.3$ & $4.4 \pm 0.4$ & $100 \pm 3.2$ & $25.4 \pm 3.0$ & $101 \pm 4.0$ & $6.6 \pm 0.9$ \\
\hline Odi & $141 \pm 2.2$ & $4.0 \pm 0.5$ & $103 \pm 3.6$ & $29.8 \pm 4.4$ & $97.7 \pm 4.0$ & $6.0 \pm 0.7$ \\
\hline P Value & $<0.0001(\mathrm{~S})$ & $<0.0001(\mathrm{~S})$ & $<0.0001(\mathrm{~S})$ & $<0.0001(\mathrm{~S})$ & $<0.0001(\mathrm{~S})$ & $<0.0001(\mathrm{~S})$ \\
\hline
\end{tabular}

S = Significant

Table 10: Mean and SD Values of Haematological Parameters in the Study Populations.

\begin{tabular}{|l|l|l|l|l|}
\hline $\begin{array}{l}\text { STUDY } \\
\text { COMMUNITY }\end{array}$ & Hb $(\mathbf{g} / \mathbf{d l})$ & WBC $(\times \mathbf{1 0} \mathbf{9} / \mathbf{l})$ & Platelet $(\times \mathbf{1 0} \mathbf{9} / \mathbf{l})$ & PT (Seconds) \\
\hline Imiringi & $11.3 \pm 1.9$ & $5.8 \pm 0.55$ & $186.3 \pm 6.3$ & $13.87 \pm 1.14$ \\
\hline Odi & $12.02 \pm 1.5$ & $6.6 \pm 0.63$ & $208.5 \pm 7.5$ & $12.74 \pm 1.1$ \\
\hline P Value & $<0.0001(\mathrm{~S})$ & $<0.0001(\mathrm{~S})$ & $<0.0001(\mathrm{~S})$ & $<0.001(\mathrm{~S})$ \\
\hline
\end{tabular}

S=Significant 


\section{DISCUSSION}

High levels of bioaccumulation of heavy metals (Cadmium, Chromium, Mercury, Lead and Selenium) in the blood samples of residents in the gas flaring community in relation to the control community was observed as shown by the results obtained from this study. Oxides of these metals are released in large amounts into the atmosphere continuously through the process of gas flaring. Inhalation of oxides of these metals by residents of this community may result in increased metal uptake [26]. Up to $10-40 \%$ retention of inhaled Cadmium in the human body had been reported [26]These released metal oxides also mix with rain water and are equally deposited on vegetation, and water bodies in the community which are in turn consumed by the residents [27] [28]. These facts point to the possible reason for the high levels of the measured heavy metals in the residents of the gas flaring community. Though females in the gas flaring community (Imiringi) had the highest levels of all the metals, statistically significant difference was only observed in selenium and there was no clear definitive pattern in the levels of the measured metals in both sexes. Significantly higher blood levels of lead and cadmium [29] cadmium [30] lead [31] Cadmium, Chromium and Mercury [32] and nickel [33] in males than females were reported by different authors. On the other hand, some other authors [34] and [30] reported no difference in males and females. An assessment of the trend of heavy metal bioaccumulation in the different age groups of the subjects shows that bioaccumulation of measured metals increased significantly with age.The measured serum levels of the lipid peroxidation biomarker (8-Isoprostaglandin $F_{2} \alpha$ ) was higher in Imiringi residents than in the control community same as observed in the measured metals thus, suggesting that the metals elicited the production of higher levels of 8-Isoprostaglandin $F_{2} \alpha$ as can be seen in the observed positive and significant correlations between them. Chromium and selenium are redox active and therefore undergo redox cycling while cadmium, mercury and lead which are redox in-active deplete cells' major antioxidants; particularly thiol containing antioxidants and enzymes. Both redox-active and redox-inactive metals may induce an increase in the production of reactive oxygen species such as the hydroxyl radical (HO-) superoxide radical $\left(\mathrm{O}_{2}{ }^{-}\right)$or hydrogen peroxide $\left(\mathrm{H}_{2} \mathrm{O}_{2}\right)$ which in turn elicits the increased production 8-Isoprostaglandin $\mathrm{F}_{2} \alpha$ in the subjects. Lead is harmful to almost all systems of the body and effects of its exposure are irreversible. Lead exposure is perhaps best associated with its negative impact on human intelligence [35].This is due to extreme vulnerability of the brain to lead poisoning. [36], Lead affects the red blood cells as well as the hematopoietic system, the immune system and also causes damage to organs such as the liver, kidneys, heart and male gonads [34] Exposed persons experience a suppressed immune system as well as increased blood pressure. [37]. Lead poisoning is a huge concern for pregnant women. Chronic low level exposure can accumulate and remain in the bones until pregnancy occurs when calcium demand increases. This can dislodge lead deposits into the blood stream causing harm to the pregnant mother and the developing fetus [38]. Exposure to mercury (even small amounts) may cause serious health problems, and is a threat to the development of the child in utero and early life. Elemental and methylmercury are toxic to the central and peripheral nervous systems. The inhalation of mercury vapour can produce harmful effects on the nervous, digestive and immune systems, lungs and kidneys and may be fatal. Residents from Imiringi may also be prone to neurological and behavioural disorders which are observed after inhalation, ingestion or dermal exposure of different mercury compounds. Symptoms include tremors, insomnia, memory loss, neuromuscular effects, headaches and cognitive and motor dysfunction. Owing to the observed high levels of chromium, residents in Imiringi may as well be exposed to chromium toxicity after inhalation which includes dermatitis, allergic and eczematous skin reactions, skin and mucous membrane ulcerations, perforation of the nasal septum, allergic asthmatic reactions, bronchial carcinomas, gastroenteritis, hepatocellular deficiency and renal oligo anuric deficiency. (PC) Exposure to Cadmium can cause a variety of pathological alterations in several organs and tissues as well as induce diabetic complications, hypertension and osteoporosis [34]. The results of this study are highly suggestive of a higher possibility of occurrence of renal impairment in the residents of the gas flaring community as observed in the statistically significantly increased levels of serum urea and serum creatinine measured in residents of Imiringi community compared to those in the control group. This is in line with the findings by Egwurugwu et al 2013 [27] and Ifenkwe et al., 2017 [32] who also reported statistically significantly increased serum concentrations of urea, creatinine, potassium, uric acid and inorganic phosphate in subjects exposed to gas flares and oil spillage respectively. Exposure to gas flares is known to cause some adverse changes in hematological parameters. These changes affect blood and blood-forming cells negatively and could lead to anemia (aplastic), pancytopenia and leukemia [39]. The measured hematological indices equally show that the residents in the gas flaring community may be prone to anemia due to significantly lower levels of hemoglobin measured among them. They may also be prone to suppressed immunity as well as bleeding disorders as evidenced by the significantly lower levels of WBC, platelets and longer prothrombin time measured in their blood samples as compared to the control. 


\section{CONCLUSION}

There is bioaccumulation of Cadmium, Chromium, Lead, Mercury and Selenium and a corresponding high level of 8Isoprostaglandin $\mathrm{F}_{2} \alpha$ in the blood samples of residents in Imiringi community supporting the influence of heavy metals in elicitation of reactive oxygen species and inducement of oxidative stress. The findings of this study therefore suggest that chronic exposure to these measured heavy metals may result to oxidative stress which is an indicator for likely occurrence of diseases associated with oxidative damage such as atherosclerosis, kidney damage, liver damage, respiratory disorders, neurodegenerative diseases, such as multiple sclerosis, amyolotrophic lateral sclerrosis Alzheimer's and Parkinson's disease, cancer, diabetes mellitus and chronic inflammatory diseases among residents in Imiringi community.

\section{RECOMMENDATIONS}

With regards to the stated health implications of exposure of communities to gas flares and the poor regulation of oil producing activities in these places, it is strongly recommended that strict compliance to all safety standards, regulations and guidelines aimed at achieving safe oil exploration and production must be followed strictly to reduce and if possible avoid contamination of the environment with pollutants. A comprehensive investigation of the heavy metal content of foods and water consumed in these communities should be performed. Since the production of isoprostanes is well documented to increase in direct proportion with the level of oxidative stress it will be valuable to employ its measurement in the assessment of exposure status of residents in environmentally impacted areas. The use of antioxidants in the treatment of metal induced toxicity deserves further consideration as oxidative stress is scientifically proven to be an important mechanism for heavy metal toxicity.

\section{REFERENCES}

1. Ajugwo, A.O. (2013). Negative Effects of Gas Flaring: The Nigerian Experience. Jeph 1, $6-8$.

2. Kakulu, S.E. (1985). Heavy Metals in the Niger Delta: Impact of Petroleum Industry on the Baseline Levels. Ph.D Thesis University of Ibadan.189 - 219.

3. Akporhonor, E.E., Iwegbue, C.M.A., Egwaikikhide, P.A and Emua, S.A. 2007 Levels of Cadmium, Lead and Mercury In Organs of some Fish Species from Warri River, Nigeria. J. Chem. Soc. Nigeria, 32 (1) 221-226.

4. Duane, M.E. and James, Y.K. (1997) Cellular and Molecular Mechanisms of Metal Toxicities, CRC Press, New York:

5. Szymańska-Chabowska, A., Beck, A., Poręba, R., Andrzejak, A. and Antonowicz- Juchniewicz, J. (2009). Evaluation of DNA Damage in People Occupationally Exposed to Arsenic and Some Heavy Metals Polish J. Environ. Stds.,. (18):1131-1139.

6. Durackova, Z. (2010). Some Current Insights into Oxidative Stress. Physio. Res., (59):459 - 468.

7. Roberts, L. J., and Morrow, J. D. (2000).Measurement of F2-isoprostanes as an index of oxidative stress in vivo. Free Radic. Biol. Med. 28, 505-513.

8. Gutteridge, J. M. and Halliwell, B. (1990). The Measurement and mechanism of lipid peroxidation in biological systems. Trends Biochem. Sci. 15, 129-135.

9. Halliwell, B. (2000) Lipid peroxidation, antioxidants and cardiovascular disease: how should we move forward? Cardiovasc. Res. 47, 410-418.

10. Gay, C. A. and Gebicki, J. M. (2003). Measurement of protein and lipid hydroperoxides in biological systems by the ferricxylenol orange method. Anal. Biochem. 315, 29-35.

11. Gopaul, N. K., Halliwell, B., and Anggard, E. E. (2000). Measurement of plasma F2 isop-rostanes as an index of lipid peroxidation does not appear to be confounded by diet. Free Radic. Res. 33, 115-127.

12. Richelle, M., Turini, M. E., Guidoux, R., Gavazzi, I., Metairon, S., and Fay, L. B. (1999). Urinary isoprostane excretion is not confounded by the lipid content of the diet. FEBS Lett. 459, 259-262.

13. Godson, R.E., Myenpali, N.A., Sridhar, K..C. (2004). Soil Quality near a Chemical Fertilizer Industry of Port Harcourt, Nigeria. AJEAM 8:19-26. 
Ifenkwe john C. et. al., Heavy Metal Bioaccumulation And Lipid Peroxidation Damage

14. Gobo, A., Richard, B and Ubong, I. (2010) Health Impact of Gas Flares on Igwuruta/Umuechem Communities in Rivers State. J.Appl. Sci.(3) 27 - 33.

15. John, K. N., Orish, E. O. and Linus, O. E. (2008) Some Physiochemical Parameters of Potable Water Supply in Warri, Niger Delta Area of Nigeria. Scientific Research and Essay. 3 (11): 547 - 551.

16. Egwurugwu J.N., Nwafor A., Nwankpa P., Olorufemi O.J., Okwara J.E. (2013). Prolonged Gas Flaring and Water Quality in Obiakpu, Egbema Imo State Nigeria, Inter. Res. J. Med. Sci... 2(4): 1-5 (107): $39-44$.

17. Saito, S., Yamauchi, H., Hasul., Y., Kurashige, J., Ochi and Yoshida, K. (2000). Quantitative Determination of 8Hydroxydeoxyguanosine by Using ELISA, Research Communications in Molecular Pathology and Pharmacology (107): $39-44$

18. Doumas, B. T., Watson, W.A, and Briggs, H.G. (1971). Albumin Clinica Chimica Acta (31): 87-96.

19. Jendrassik, L. and Grof, P. (1938). Bilirubin, Biochemistry (81): 297.

20. Kochmar, J.F. and Moss, D.W. (1976). Fundamentals of Clinical Chemistry Tietz Edition. W.B. Saunders and Company, Philadelphia: 604 101-117.

21. Reitman, S and Frankel, S (1957) Alanine Aminotransferase. American Journal of Clinical Pathology (28): 56.

22. Slot, C., 1965. Scand. J. Clin. Lab. Inv., (17) 381- 387.

23. Vanencia, A., Arulselvi, S., Kanchana, R. And Ravindra, M.P. (2011). Agreement of Two Different Laboratory Methods Used to Measure Electrolytes. Journal of Laboratory Physicians (2): 104-109.

24. Whisler, S and Dahlgren, C. 2005. Performance Evaluation of the Sysmex poch-100i Automated Haematology Analyzer Laboratory Haematology (2):

25. Dacie, J.V and Lewis, S.M. 198). Practical Hematology: 120.

26. Friberg, I. (1995) Cadmium in the Environment, CRC Press, Cleveland: $56-58$.

27. Egwurugwu J.N., Nwafor A. , Oluronfemi O.J.. Iwuji S.C. and Alagwu E.A. (2013).Impact of Prolonged Exposure to Oil and Gas Flares on Human Renal Functions. Inter. Res. J. Med. Sci.. 1(11): 9-16.

28 . Nwankwo C.N. and Ogagarue D.O. (2011). Effects of Gas Glaring on Surface and Ground Waters in Delta State Nigeria. J. Geo. Min. Res., 3(5): 131-136.

29. Sirivarasai, J., Kaojaren, S., Wananukul, W., Srisomerang, P. (2002) Non- Occupational Determinants of Cadmium and Lead in Blood and Urine Among a General Population in Thailand. Southeast Asian Journal of Tropical Medicine and Public Health, 33(1): 180-187.

30. Khassouani, C.E., Soulaymani, R., Mauras, Y., Allain, P. (2000). Blood Cadmium Concentration in the Population of Rabat Area, Morocco. Clinica Chimica Acta, 302(1-2): 155-160

31. Bushnik, T., Haines, D., Levallois, P.,Levesque, J., Van Oostdam, J., Viau, C (.2010) Lead and bisphenol A concentrations in the Canadian population. Health Reports, 21(3): 1-12.

32. Ifenkwe, J. C., Nwanjo, H. U., Nwosu D. C. and Ofor, I. B. (2017). Toxicological Studies on Heavy Metal Bioaccumulation and Oxidative DNA Damage in Residents of a Gas Flaring Community. Int. J. Sci. Res., 6

(12) $1868-1875$

33. Ibeto, C.N and Okoye, C.O.B. (2010). High levels of Heavy Metalsin Blood of the Urban Population of Nigeria. Res. J. Environ.l Sci., (4): 371- 382.

34. Olsson, I.M., Bensryd, I., Lundh, T., Ottosson, H., Skerfving, S., Oskarsson, A.. (2002). Cadmium in Blood and Urine -Impact of Sex, Age, Dietary Intake, Iron Status, and Former Smoking - Association of Renal Effects. Environ. Health Persp., 110(12): 1185-1190.

35. Iglesias, V., Steenland, K., Masionet, M and Pino, P.2011. Exposure to lead from a storage siteassociated with intellectual impairment in Chilean children living nearby. Int. J. Occup.Environ. Health 17 (4): $314-321$.

36. Manto, M. 2012. Toxic agents causing cerebellar ataxias. Handb. Clin. Neurol.,103:201 -213. 
International Journal of Advances in Scientific Research and Engineering (ijasre), Vol 4 (7), July - 2018

37. Garcia-Leston,J., Roma-Torres, J., Mayan, O., Schroecksnadel, S., Fuchs, D., Moreira, A.O., Pasaro,E., Mendez, J., Teixeria, J.P.and Laffon, B. (2012). Assessment of immunotoxicity parameters in individuals occupationally exposed to lead. J. Toxicol. Environ. Health . 75 (13- 15): 807 - 818

38. Vigeh, M., Saito, H and Sawada, S. (2011). Lead exposure in female workers who are pregnant or of childbearing age. Ind. Health 49 (2): $255-261$.

39. Achparaki, M., Thessalonikeos, E., Tsoukali,H., Mastrogianni, O., Zaggelidou E., Chatzinikolaou, F., Vasilliades, N and Raikos, N 2012. Heavy Metals Toxicity.Arist. Uni. Med. J. 39(1): 29 -34. 